\title{
SISTEM PRESIDENSIAL INDONESIA MASA KEPEMIMPINAN PRESIDEN SOESILO BAMBANG YUDHOYONO (2004-2014)
}

\author{
Asran Jalal ${ }^{1}$ \\ ${ }^{1}$ Program Studi Ilmu Politik Sekolah Pascasarjana, Universitas Nasional \\ Email: asran_jalal@yahoo.com.
}

(Submission 03-08-2021, Revissions 16-09-2021, Accepted 23-09-2021)

\begin{abstract}
Indonesia after the amandement of the 1945 Constitution (UUD 45), implemented a presidential system side by side with a multi-party system. This system came into effect postelection in 2004, namely during the leadership of President Sosilo Bambang Yudhoyono who ruled for two periods from 2004 to 2014. During the leadership of President Soesilo Bambang Yudhoyono, Indonesia's presidential system relatively stable, what political scientists feared that such a presidential system model made possibility of a political deadlock between the president and DPR not accurring, even though the opportunity was open, especially in the Century Bank bailout case. The conflict between Presiden Soesilo Bambang Yudhoyono and the DPR during his reign was only limited to conflict in the exercise of their respective powers. The presidential system model ini this period can support the stability of Indonesia's democracy. This situation is supported by the leadership of President Soesilo Bambang Yudhoyono who prioritizes the politics accommodation and avoid open conflict in exercising his power. The implications of such scale political corruption cases involving state officials.
\end{abstract}

Keywords: Indonesia presidential system, multiparty, coalition, democratic stability, leadership of president Soesilo Bambang Yudhoyono.

\begin{abstract}
Abstrak
Indonesia pasca-amandemen Undang-Undang Dasar 1945 (UUD 45), memberlakukan model sistem presidensial berdampingan dengan sistem multipartai. Sistem ini mulai berlaku pascapemilu tahun 2004 yaitu pada masa kepemimpinan Presiden Soesilo Bambang Yudhoyono yang memerintah selama dua periode, 2004-2014. Masa kepemimpinan Presiden Soesilo Bambang Yudhoyono, sistem presidensial Indonesia relatif stabil, apa yang dikhawatirkan para ilmuwan politik model sistem presidensial yang demikian itu membuat peluang terjadinya political deadlock antara presiden dan DPR tidak terjadi, meskipun peluang itu terbuka, terutama dalam kasus bailout Bank Century. Konflik antara Presiden Soesilo Bambang Yudhoyono dengan DPR masa pemerintahannya hanya sebatas konflik dalam melaksanakan kekuasaan masing-masing. Model sistem presidensial pada periode ini, dapat menopang stabilitas demokrasi Indonesia. Situasi ini didukung oleh kepemimpinan Presiden Soesilo Bambang Yudhoyono yang mengutamakan politik akomodasi dan menghindari konflik terbuka dalam melaksanakan kekuasaannya. Implikasi model kepemimpinan
\end{abstract}


presiden yang seperti itu, menghambat menyelesaian kasus korupsi politik berskala besar yang melibatkan pejabat negara.

Kata Kunci: sistem presidensial Indonesia, multipartai, koalisi, stabilitas demokrasi, kepemimpinan presiden Soesilo Bambang Yudoyono

\section{PENDAHULUAN}

Idealnya, sistem presidensial dikombinasikan dengan sistem dwipartai. Hasil studi yang dilakukan para ilmuwan politik di berbagai negara, terutama di negara-negara di Amerika ketika memulai proses demokratisasi menunjukkan bahwa kombinasi model sistem presidensial dengan sistem dwipartai yang yang dipraktekkan di Amerika Serikat dianggap ideal karena mendukung stabilitas demokrasi sistem presidensial. Ini berbeda dengan sistem pemerintahan presidensial apabila berdampingan dengan sistem multipartai, yang memiliki resiko dan dapat mengancam stabilitas demokrasi.

Beberapa resiko yang ditemui di negara-negara penganut sistem presidensial yang dikombinasikan dengan sistem multipartai antara lain adalah munculnya situasi ketidakharmonisan antara presiden dan parlemen, dan berujung pada kebuntuan politik (political deadlock). Individu yang terpilih menjadi presiden belum tentu menjadi kelompok mayoritas di parlemen. Kondisi ini bisa menghasilkan 'tirani minoritas' karena presiden memiliki hak prerogatif dalam membuat agenda politik, tanpa harus persetujuan parlemen (Linz, 1990).

Periode jabatan presiden yang tidak dapat disela (fixed term), berkonstribusi bagi pembusukan dan ancaman demokrasi, karena tidak adanya prosedur yang dapat mengontrol secara efektif jalannya pemerintahan pascapemilu. Anggota legislatif atau rakyat harus menunggu jangka waktu tertentu untuk menghukum presiden yang tidak lagi sejalan dengan cita-cita bersama dan ingkar terhadap janji kampanye. Pada sistem pemerintahan parlementer, anggota parlemen dapat mengganti (governmental refreshing) perdana menteri manakala kebijakan-kebijakan perdana menteri dipandang tidak sejalan dengan parlemen (Juan Linz, 1990). Problem lainnya adalah presiden menemui kesulitan dalam membangun koalisi dengan partai politik untuk membangun pemerintahan yang stabil (Haris, 2011).

Indonesia pasca amandemen UUD 1945 yang mulai berlaku pada tahun 2004 menganut sistem presidensial dengan sistem multipartai. Beberapa ciri sistem presidensial Indonesia yaitu pemilihan presiden (pilpres) dilaksanakan secara langsung, pemilihan umum (pemilu) anggota-anggota legislatif atau anggota DPR (pileg) dilaksanakan dengan menggunakan sistem proporsional dan sistem multipartai. Pileg tahun 2004, partai politik yang ikut sebagai peserta sebanyak 24 partai politik dan pada pileg tahun 2009 diikuti sebanyak 38 partai politik (Subekti, 2008).

Model sistem presidensial seperti Indonesia ini mengkhawatirkan kalangan ilmuwan politik Indonesia karena dapat menimbulkan berbagai masalah, antara lain berupa terjadinya kebuntuan (deadlock) dalam hubungan presiden dengan DPR, karena kedua lembaga ini merasa memiliki legitimasi. Kebuntuan politik (political 
deadlock) dalam hubungan presiden-parlemen dapat terjadi, karena hal tersebut melekat dengan sistem presidensial. Penyebab terjadinya kebuntuan hubungan presiden-DPR dalam sistem presidensial di Indonesia disebabkan oleh karakter para politisi yang menjadi presiden dan anggota DPR (Rauf, 2009).

Kekhawatiran lainnya adalah, dapat menimbulkan impeachment yang dilakukan DPR kepada presiden, karena kedua lembaga ini memiliki kekuasaan yang berimbang, presiden yang kuat dan DPR yang kuat (Magenda, 2007). Problem lainnya adalah presiden akan menemui kesulitan dalam membangun koalisi partai politik untuk membangun pemerintahan yang stabil. Model sistem presidensial yang demikian dapat melahirkan pemerintahan yang terbelah (divided government) yakni presiden menjalankan kekuasaannya tanpa harus memperoleh dukungan DPR (Romli, 2019).

Era pemerintahan Presiden Soesilo Bambang Yudoyono (Presiden SBY) sepanjang tahun 2004-2014, problem politik yang dihadapi Presiden SBY dan Partai Demokrat (PD) sebagai partai Presiden SBY adalah menjadi partai minoritas di DPR. Hasil pileg tahun 2004, PD memperoleh suara sebesar 7,4\%, dan pada pileg tahun 2009, PD memperoleh suara sebesar 20,81\%. Strategi Presiden SBY menghadapi kondisi ini adalah dengan membangun partai koalisi dalam rangka mendukung kebijakan presiden, baik di DPR maupun di luar lembaga DPR (Suryadinata, 2002).

Problem berikutnya yang dihadapi Presiden SBY adalah institusi DPR sebagai institusi pengawas presiden memiliki legitimasi, era legislative heavy. Anggota DPR hasil pileg tahun 2004 berjumlah 560 orang terdiri dari 9 fraksi. Jumlah anggota DPR hasil pileg 2009 berjumlah 560 orang terdiri dari 9 fraksi (dpr.go.id). Kedudukan DPR yang demikian mengharuskan Presiden SBY menghadapi tekanan DPR. Pada periode 2004-2009, Presiden SBY menghadapi sebanyak 14 kali usulan hak interpelasi, dan 9 kali hak angket DPR (Haris, 2011). Periode kedua Presiden SBY mengahadapi tekanan DPR dalam kasus dana talangan (bailout) Bank Century.

Presiden SBY selama 10 tahun memerintah, mampu mengelola sistem presidensial Indonesia dan dapat mencegah terjadinya political deadlock dengan DPR, tanpa terhambatnya proses demokrasi Indonesia. Pertanyaan yang diajukan yaitu mengapa Presiden SBY mampu bertahan menjadi presiden selama 2 periode di tengah sistem multipartai? Apa faktor pendukung utamanya? Bagaimana model kepemimpinan Presiden SBY dalam menjalankan kekuasaannya?

Argumen yang diajukan dalam studi ini adalah stabilitas sistem presidensial berdampingan dengan sistem multipartai pada masa kepemimpinan Presiden SBY tidak bisa dipisahkan dari prilaku kepemimpinannya yang mempraktekkan politik akomodasi dan menghindari konflik terbuka.dalam melaksanakan kekuasaannya.

\section{Tinjauan Pustaka}

Studi ini menggunakan teori sistem presidensial, teori koalisi sistem presidensial, dan teori kepemimpinan presiden. Arend Lijphart (1992) membahas tentang ciri sistem presidensial. Beberapa ciri sistem presidensial antara lain adalah, 
eksekutif dan legislatif terpisah satu sama lain, berbeda dengan sistem parlementer dimana eksekutif dan parlemen merupakan satu kesatuan. Kelebihan dari sistem pemerintahan presidensial antara lain adalah stabilitas eksekutif, karena masa jabatan presiden bersifat tetap (fixed term). Kelemahannya adalah masalah konflik eksekutif dengan legislatif yang dapat mengarah kepada jalan buntu (deadlock). Pola hubungan eksekutif dan legislatif dalam konteks sistem demokrasi diwarnai oleh dua kecenderungan utama, yaitu pola hubungan yang yang bersifat dominasi satu lembaga atas yang lain, baik dominasi eksekutif atas legislatif atau sebaliknya dan pola seimbang (Lijphart, 1984).

Matthew S. Shughart \& Carey J.M (1992) menjelaskan tentang perbedaan sistem persidensial dan sistem parlementer. Pemerintahan presidensial cenderung lebih efisien daripada parlementer. Efisien merujuk kepada kemampuan pemilih untuk mengidentifikasi komposisi pemerintahan akhir di depan. Pemilih dapat mengidentifikasi siapa yang akan menjadi presiden sebelum penetapan suara final. Sistem parlementer tidak seefisen itu, karena komposisi pemerintahan akhir tergantung pada dinamika politik terkait pembentukan koalisi pemerintahan. Aspek representasi, merujuk pada seberapa banyak populasi terwakili oleh pemerintahan yang berkuasa. Presiden dalam sistem presidensial jarang merepresentasi seluruh rakyat. Contohnya adalah kemenangan Salvandor Allende pada pemilihan 1970 di Cile dengan hanya memperoleh suara $30 \%$ pemilih. Sistem parlementer, representasi dari pemilih dengan mudah dicapai melalui pemerintahan koalisi.

Perbedaan sistem presidensial dan sistem parlementer yaitu, pertama sistem presidensial membuat pemisahan kekuasaan eksekutif, legislatif, dan yudikatif secara tegas. Legislatif membuat hukum, eksekutif menjalankan hukum, dan yudikatif menafsirkan hukum. Sistem parlementer membuat pembagian kekuasaan kurang tegas, karena legislatif dan eksekutif bercampur bersama. Kedua, presiden dipilih langsung oleh oleh seluruh rakyat. Sistem pemilihan dengan beberapa variasi berupa pemenang harus memperoleh lebih $50 \%$ suara pemilih (simple-majority voting system), dalam sistem ini tidak ada pemenang masyoritas langsung (clear-cut majority), dua peraih suara terbanyak akan bersaing pada pemilihan final (two round system). Sistem tidak langsung (electoral college) dilaksanakan untuk memilih presiden. Kasus Amerika Serikat, Partai Republik adan Partai Demokrat memilih sejumlah elektor untuk setiap negara bagian, jumlahnya setara dengan jumlah anggota House of Representatif dan senator di negara bagian. Kandidat presiden dinyatakan sebagai pemenang apabila memperoleh mayoritas suara Electoral College yakni 270.

Ketiga, masa jabatan presiden bersifat pasti (fixed terms), tidak tergantung dukungan legislatif, kecuali presiden melakukan penyalahgunaan kekuasaan (abuse of power) dibuktikan di pengadilan. Pada sistem parlementer, masa jabatan perdana menteri tergantung pada dukungan parlemen. Keempat, dalam sistem presidensial, presiden memiliki kekuasaan untuk membentuk kabinetnya sendiri. Sistem parlementer, penunjukkan kabinet merupakan upaya bersama partai koalisi.

Konstribusi positif sistem presidensial, pertama adalah efisiensi, yang berarti pemilih mengetahui sebelum menentukan pilihan, pemerintahan seperti apa 
yang akan terbentuk. Efisiensi memberikan pemilih banyak informasi sehingga pemilih memiliki dasar untuk memilih kandidat tertentu. Sistem parlementer kurang efisien, tergantung hasil koalisi yang akan terbentuk. Kedua, representasivitas pejabat terpilih, presiden terpilih dalam sistem presidensial mewakili seluruh wilayah negara atau mewakili seluruh pemilih. Sistem parlementer, setiap partai hanya mewakili pendukungnya saja. Ketiga, mekanisme checks and balance atau distribusi cabang kekuasaan kepada legislatif dan yudikatif, lebih tampak dalam sistem presidensial ketimbang sistem parlementer. Implikasi positif sitem parlementer adalah lebih kondusif bagi terbentuknya partai politik, khususnya sitem multipartai. Sistem presidensial cenderung membatasi partai politik (Josepp W. Robbins, 2011).

Sistem presidensial dikombinasikan dengan sistem multipartai merupakan ancaman serius (perils) bagi demokrasi, terdapat korelasi antara sistem presidensial dengan pembusukan politik (pemerintahan anti demokrasi, kekacauan politik), seperti kasus yang terjadi di negara-negara Amerika Latin. Sistem presidensial menghasilkan 'tirani minoritas', karena orang yang terpilih menjadi presiden belum tentu menjadi kelompok mayoritas di parlemen. Kondisi ini bisa berimplikasi munculnya situasi ketidakharmonisan antara presiden dan parlemen dan berujung pada kebuntuan (deadlock). Situasi ini didukung oleh kekuasaan presiden yang memiliki hak prerogatif dalam membuat agenda politik, tanpa harus persetujuan parlemen. Sistem parlementer, perdana menteri merupakan kelompok mayoritas dalam parlemen, kebijakan-kebijakan perdana menteri sejak awal sudah disepakati parlemen (Linz, 1990).

Periode jabatan presiden yang tidak dapat disela (fixed term), berkonstribusi bagi pembusukan dan ancaman demokrasi, karena tidak adanya prosedur yang dapat mengontrol secara efektif jalannya pemerintahan pascapemilu. Anggota legislatif atau rakyat harus menunggu jangka waktu tertentu, untuk menghukum presiden yang tidak lagi sejalan dengan cita-cita bersama dan ingkar terhadap janji kampanye. Sistem pemerintahan parlementer, anggota parlemen dapat mengganti (governmental refreshing) perdana menteri, manakala kebijakan-kebijakan perdana menteri dipandang tidak sejalan dengan parlemen (Linz, 1990).

Scott Mainwaring (1993) menyebutkan bahwa kombinasi sistem multipartai dan sistem presidensial tidak kondusif untuk stabilitas demokrasi. Alasannya: pertama, sistem presidensial kombinasi bisa menghasilkan konflik parlemen dan presiden yang panjang, beresiko terjadinya kelumpuhan kelembagaan (immobilitas), bisa terjadi kebuntuan politik (political deadlock) dalam relasi eksekutif-legislatif, kebuntuan akan berujung pada instabilitas demokrasi. Kedua, sistem multipartai menghasilkan polarisasi ideologis yang bisa menimbulkan masalah kompilasi ketika berdampingan dengan sistem presidensial. Ketiga, kombinasi sistem presidensial dengan multipartai, terjadi kesulitan dalam membangun koalisi antarpartai, berimplikasi pada rusaknya stabilitas demokrasi presidensial.

Jose Antonio Cheibub (2007) berpandangan sistem presidensial tidak memiliki bahaya terhadap stabilitas demokrasi. Ancaman demokrasi dalam sistem persidensial berasal dari kondisi-kondisi sosial yang mendasari atau karakteristik 
latar belakang rezim sebelumnya. Apakah rezim sebelumnya rezim militer atau sipil, karena banyak negara Amerika Latin telah mengalami pemerintahan kediktatoran militer. Pemerintahan minoritas dalam sistem presidensial dan deadlock, tidak mempengaruhi kelangsungan demokrasi presidensial. Pemerintahan terbelah (divided government) terjadi jika: (1) tingginya jumlah partai politik yang efektif; (2) pemilihan legislatif dan eksekutif tidak bersamaan; (3) sistem pemilihan umum bersifat proporsional. Mencegah deadlock dan pemerintahan terbelah, perlu institusi veto untuk menguatkan kekuasaan presiden. Sistem presidensial dapat memelihara stabilitas demokrasi dengan cara menawarkan kepada para pemilih kesempatan untuk mempengaruhi proses pembuatan kebijakan (Josepp W. Robbins, 2011).

Studi sistem presidensial Indonesia post-Soeharto antara lain ditulis oleh Burhan D. Magenda, Maswadi Rauf, Syamsuddin Haris, dan Lili Romli. Magenda (2007) mengemukakan hubungan eksekutif dan legislatif Indonesia telah beralih dari dominasi sistem presidensialisme selama masa Orde Baru ke arah keseimbangan antara sistem parlementarisme masa reformasi pascaamandemen UUD 1945. Indonesia menjurus kepada sistem presidensial yang kuat dan parlemen yang kuat. Sistem ini melahirkan problem, jika presiden tidak memiliki mayoritas dukungan di parlemen, bisa menimbulkan impeachment.

Hubungan Presiden SBY dan DPR selama periode 2004-2014 belum dapat dikatagorikan sebagai masalah karena tidak ada konflik yang berarti antara kedua lembaga politik tersebut. Perbedaan pendapat antara keduanya selalu terjadi, karena DPR memiliki fungsi pengawasan terhadap eksekutif, seperti kehendak DPR agar Presiden SBY hadir memberikan keterangan hak interpelasi di hadapan DPR. Pemerintah merespon kehendak DPR dengan menyatakan keterangan presiden dapat diwakili oleh menteri terkait. Kelumpuhan dan kebuntuan politik yang berujung pada kudeta tidak mungkin terjadi di Indonesia, karena tidak ada partai yang ekstrim, baik ekstrim kiri maupun ekstrim kanan, selain itu juga tidak ada tradisi kudeta militer seperti di negara-negara Amerika Latin. Kebuntuan politik (Political deadlock) dalam hubungan presiden-parlemen dapat terjadi, karena hal tersebut sudah melekat pada sistem presidensial. Penyebab kebuntuan politik dalam sistem presidensial di Indonesia bukan disebabkan masalah politik, tapi disebabkan oleh karakter para politisi yang menjadi presiden dan anggota DPR (Rauf, 2009).

Kebuntuan politik dapat saja terjadi pada masa Presiden SBY mengingat Presiden SBY memiliki basis dukungan minoritas. Presiden SBY mampu mencegahnya melalui politik kompromi dan pluralis-pragmatis. Langkahnya adalah mendukung kepemimpinan Jusuf Kalla menjadi Ketua Umum Partai Golkar dan membangun Kabinet Pelangi yang terdiri dari beberapa partai politik (Firman Noer, 2009). Masalah disharmonisasi akibat timbulnya dual legitimasi, dimana presiden dan DPR merasa memiliki legitimasi yang sama, bila tejadi persoalan dikhawatirkan dapat terjadi kebuntuan politik. Presiden membuat kebijakan tanpa dukungan DPR. Masa Presiden SBY hal itu dapat saja terjadi. Presiden SBY dapat mencegahnya melalui komunikasi formal dan informal melalui menteri-menterinya dengan pihak DPR. Personalisasi kekuasaan dalam pengertian kecenderungan presiden semakin otoriter akibat kontrol yang tidak efektif dan luasnya kekuasaan presiden dalam 
menyusun kabinet dan membuat program kerja seperti di Brazil dan Argentina, mungkin saja terjadi di Indonesia, namun Presiden SBY cenderung kompromi dan mengakomodir semua kelompok.

Kabinet yang tidak didukung koalisi yang solid masa Presiden SBY 20092014 terjadi dalam kasus kebijakan SBY terhadap kenaikan Bahan Bakar Minyak (BBM) tahun 2012, yang tidak didukung oleh partai koalisi di DPR. Partai koalisi tidak melakukan pembelaan terhadap kebijakan presiden. Partai politik pada umumnya hendak ikut koalisi, namun tidak tegas dalam mendukung dan menolak kebijakan presiden (Romli 2019). Solusinya adalah memperkuat model sistem presidensial Indonesia melalui: (1) penguatan kedudukan presiden dengan cara mengembalikan kewenangan presiden yang diintervensi DPR; (2) pelembagaan koalisi berbasis platform, yang diikat dengan kontrak politik dan dilakukan secara transparan sampai akhir pemerintahan; (3) Pemilu presiden (Pilpres) dan Pemilu legislatif (Pileg) secara serentak; (4) penyederhanaan sistem kepartaian melalui sistem distrik (Romli, 2019).

Koalisi partai dalam sistem presidensial merupakan persekutuan dua partai politik atau lebih yang didasarkan pada kepentingan politik dan platform politik yang sama (Lijphart, 1999). Model koalisi partai politik yaitu: (1) minimal winning coalition atau koalisi minimal yakni koalisi yang dibangun untuk memaksimalkan kekuasaan. Koalisi model ini biasanya mengabaikan partai kecil dan mengabaikan faktor ideologi partai; (2) minimum size coalition adalah koalisi yang dibangun oleh partai besar dengan partai kecil untuk sekedar mencapai suara mayoritas, koalisi ini tanpa menyertakan pertimbangan ideologi partai; (3) bargaining proposition coalition yakni koalisi partai politik jumlah sedikit biasanya dua partai, pertimbangannya memperoleh suara mayoritas sederhana, koalisi juga tanpa menyertakan pertimbangan ideologi partai; (4) minimal range coalition adalah koalisi partai politik berdasarkan pertimbangan kesamaan ideologi partai; (5) minimal connecting winning coalition yakni koalisi partai politik terjadi karena adanya persamaan orientasi kebjakan dan biasanya bersamaan dengan kedekatan ideologi partai; (6) policy-viable coalition adalah koalisi beberapa partai politik berkaitan yang memiliki kebijakan yang sama tentang suatu kebijakan khusus, koalisi ini bisa terjadi partai yang memiliki persamaan ideologi dan berbeda ideologi (Lijphart, 1999).

Problem koalisi dalam sistem presidensial Indonesia era Presiden Soesilo Bambang Yudhoyono yakni banyaknya jumlah partai yang bersaing dan pemilu menghasilkan presiden minoritas (minority president) dan pemerintahan minoritas (minority government) karena basis politik presiden tidak mencapai mayoritas sederhana di DPR. Realitas yang terjadi adalah partai koalisi tidak mendukung kebijakan presiden, periode 2004-2009 terdapat sebanyak 14 usulan Hak Interpelasi DPR kepada pemerintah. Implikasinya adalah Presiden SBY menghabiskan energi untuk melayani kepentingan DPR, sehingga produktifitas pemerintahan berkurang, akhirnya tidak melahirkan pemerintahan yang efektif. Problematikanya terletak pada personaliti presiden yang cenderung mengutamakan politik pencitraan, dan terlalu berhati-hati dalam mengambil keputusan. Karakter partai politik koalisi cenderung 
pragmatis, tidak disiplin, dan berorientasi perburuan rente (rent seeking) (Haris, 2011). Model koalisi yang dibangun pemerintahan Presiden SBY terbatas sebagai arena transaksi politik antar elite pemerintah dan politisi partai politik, tanpa dilandasi basis ideologi dan pertimbangan haluan politik yang sama (Haris, 2011).

Bakir Ihsan (2011) menyebut bahwa model koalisi yang berjalan masa pemerintahan Presiden SBY hanya sebatas ajang transaksi politik, karena presiden dan elite-elite partai tersandera oleh kepentingan yang beragam. Solusi yang ditawarkan untuk membangun koalisi yang mendukung demokrasi adalah koalisi berdasarkan persamaan ideologi (minimum connected winning coalition) dan pertimbangan kontrol yang kuat dan solid dari parlemen (minimum winning coalition).

Studi kepemimpinan politik pada dasarnya meneliti bagaimana perilaku pemimpin poltik secara individual dapat mempengaruhi proses pembuatan kebijakan dan bagaimana prilaku tersebut dapat mempengaruhi tipe keputusan yang diambil. Tiga komponen personalitas yang mempengaruhi kepemimpinan tokoh dalam membuat keputusan yaitu: (1) motif; (2) kognisi dan keyakinan, dan; (3) sifat. Motif pemimpin merujuk untuk bertidak didorong oleh motif: (1) kebutuhan akan kekuasaan; (2) prestasi; (3) afiliasi dengan orang lain. Kognisi dan keyakinan, mencakup bagaimana pemimpin menginterpretasikan, menyusun dan mengambil informasi, serta keyakinan umum pemimpin tentang sifat politik dan dunia pada umumnya. Apakah pemimpin memandang suatu masalah bersifat hitam-putih atau abu-abu. Sifat, berkaitan dengan sifat-sifat pemimpin seperti keramahan, berhati-hati (conscientiousness), keterbukaan pada pengalaman baru. Studi kepemimpinan politik dapat dilakukan pada presiden, perdana menteri, pimpinan organisasi politik seperti Sekjen PBB dan lainnya (Assche, 2011).

Studi perilaku politik memiliki dua fokus utama, yaitu tipolologi kepribadian pemimpin politik dan faktor yang mempengaruhi perilaku seorang pemimpin politik. Tipologi kepribadian pemimpin politik seperti pemimpin otoriter atau demokrat. Faktor mempengaruhi perilaku politik pemimpin yaitu: (1) lingkungan sistem politik tidak langsung, seperti sistem politik, sistem ekonomi, sistem budaya, dan media massa, dan; (2) lingkungan sosial politik langsung seperti, keluarga, agama, keluarga, dan kelompok (Smith, 20003).

Tipe kepemimpinan Presiden Amerika Serikat (AS), presiden aktif-negatif. Tipe kepemimpinan ini cenderung kompulsif dan tipe kepemimpinan berbahaya. Tipe kepemimpinan ini melekat pada Presiden Herbert Hoover, Presiden Lyndon Johnson, dan Presiden Nixon. Tipe kepemimpinan presiden aktif-positif, tipe kepemimpinan ini cenderung adaptif dan kepemimpinan yang paling sukses. Tipe kepemimpinan ini melekat pada Presiden Bill Clinton dan Presiden Jimmy Carter (James Barber, 1992). Beberapa cara yang yang digunakan oleh Presiden Amerika menghadapi tekanan kongres yaitu: (1) menggunakan perangkat informal dengan cara melakukan tawar-menawar dengan kongres dari ancaman veto, dan; (2) presiden dapat memerintahkan birokrasinya untuk tidak mengimplementasikan bagian tertentu dari undang-undang yang ditandatanganinya (Deen, 2011). 
Kekuatan kepemimpinan yang melekat pada kepemimpinan Presiden SBY, antara lain adalah moderat dan menerima kritik dengan argumentasi (Kristiadi, 2009). Berdasarkan penjelasan teoritik tersebut di atas, alur pikir stabilitas sistem presidensial berdampingan dengan sistem multipartai masa kepemimpinan Presiden SBY bisa digambarkan sebagaimana diagram pada Gambar 1.

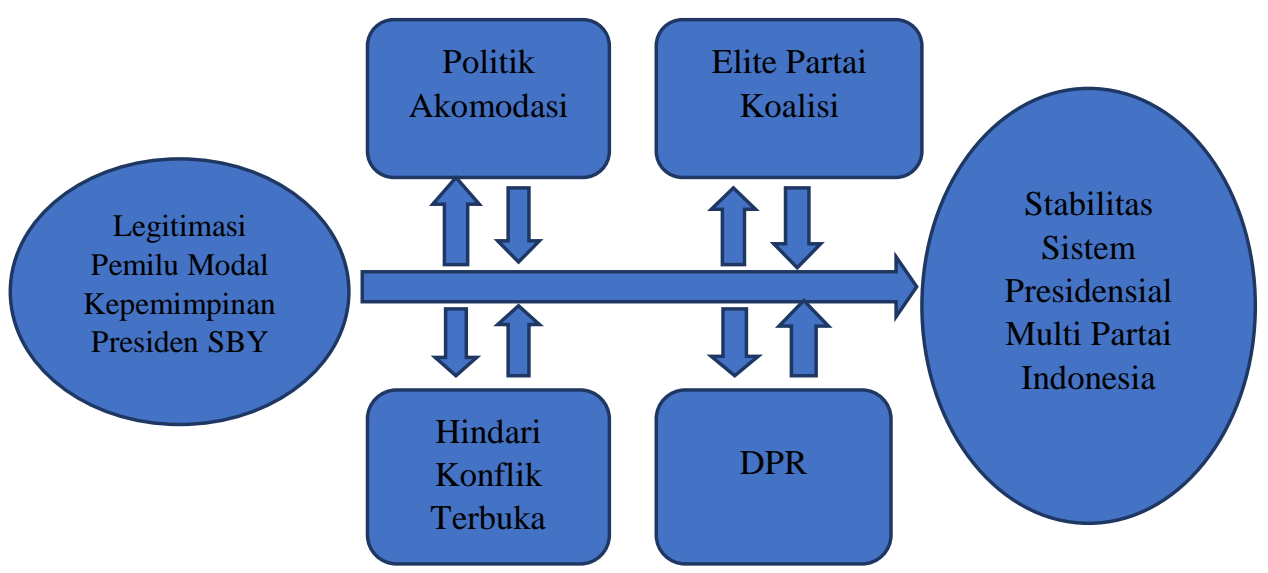

Gambar 1. Alur Stabilitas Sistem Presidensial Berdampingan Dengan Sistem Multipartai Era Kepemimpinan Presiden SBY.

\section{METODE}

Pendekatan yang digunakan dalam penelitian ini adalah pendekatan kualitatif, bercirikan induktif atau menjelaskan fenomena politik (Harrison, 2001). Tipe penelitian ini bersifat dekriptif-analitis yakni tipe penelitian yang berusaha menggambarkan realitas sosial yang kompleks melalui penyederhanaan dan klasifikasi dengan memanfaatkan konsep-konsep yang bisa menjelaskan suatu gejala sosial politik secara analitis (Jensic, 2011).

Pengumpulan data dalam penelitian ini menggunakan studi pustaka berasal dari informasi dan data yang diperoleh melalui dokumen, buku-buku, jurnal, dan media internet. Analisa data penelitian ini dilaksanakan dalam empat tahap, yaitu tahap pengecekan data, tahap pengkatagorian data dan tahap penafsiran data, serta tahap kesimpulan (Grisez \& Robert W. Kweit, 1981). Pengecekan data menggunakan tehnik triangulasi, pemeriksaan keabsahan data dengan memanfaatkan sesuatu yang lain di luar data itu untuk keperluan pengecekan atau sebagai pembanding terhadap data itu. Pengklasifikasian adalah data diklasifikasi atau dikatagori menurut urutan pembahasan dalam penelitian. Penafsiran data, mencari hubungannya data yang satu dengan data yang lainnya. Tahap pengambilan kesimpulan terhadap data dan fenomena yang sudah disusun merujuk pada pertanyaan penelitian dan teori. 


\section{HASIL DAN PEMBAHASAN \\ Legitimasi Pemilu Sebagai Modal Kepemimpinan Presiden SBY}

Presiden SBY merupakan Presiden pertama yang dipilih melalui pemilihan presiden (pilpres) secara langsung tahun 2004, dan kemudian terpilih lagi pada 2009. Pilpres tahun 2004 berlangsung dua putaran, diikuti 5 pasang calon berlangsung dua puataran. Pilpres putaran pertama, pasangan Soesilo Bambang Yudhoyono/Jusuf Kalla berhasil meraih suara terbanyak sebesar 33,58\% suara pemilih, sementara pasangan Megawati Soekarnoputri/Hasyim Muzadi berada di urutan kedua meraih suara pemilih sebesar 26,24\%. Pilpres putaran kedua, pasangan Soesilo Bambang Yudhoyono/Jusuf Kalla memperoleh suara sebesar 60,62\%, pasangan Megawati Soekarnoputri/Hasyim Muzadi meraih 39,38\%. Pilpres tahun 2009 berlangsung satu putaran, diikuti 3 pasangan calon yaitu Soesilo Bambang Yudhoyono/Budiono, pasangan Megawati Soekarnoputri/Prabowo Subianto, pasangan Jusuf Kalla/Wiranto. Pasangan calon Soesilo Bambang Yudhoyono/Budiono memperoleh suara sebesar $60,80 \%$, di urutan kedua pasangan Megawati Soekarnoputri/Prabowo Subianto dengan Raihan suara sebesar 26,79\% (kpu.go.id).

Kemenangan SBY pada pilpres 2004 dan pilpres 2009 melalui pemilu secara langsung merupakan modal politik untuk membentuk kabinet dan mengimplementasikan kebijakan-kebijakannya sebagaimana tertuang dalam visi dan misi presiden. Persoalan yang dihadapi Presiden SBY adalah Partai Demokrat yang merupakan partai presiden menjadi partai minoritas di DPR. Pileg tahun 2004, PD memperoleh jumlah kursi sebanyak 57 (7,45\%) dari 560 kursi DPR. Pileg tahun 2009 memperoleh kursi DPR sebanyak 148 kursi $(20,85 \%)$ dari 560 kursi DPR. Kekuatan Partai Demokrat yang demikian, tidak memungkinkan untuk membela kebijakan-kebijakan Presiden SBY, apabila kebijakan presiden terjadi penolakan dari anggota DPR berjumlah 505 (80\%). Kondisi inilah mengharuskan Presiden SBY membentuk koalisi dengan partai lainnya. Tujuannya adalah untuk mendudukung kebijakan-kebijakan Presiden.

Strategi yang dilakukan Presiden SBY adalah membangun partai koalisi pendukung presiden. Koalisi partai yang bergabung dengan Presiden SBY tahun 2004 yaitu Partai Demokrat dengan 58 kursi (7,45\%), Partai Golkar 128 kursi $(23,27$ $\%)$, PAN 53 kursi (9,64\%), PKS 45 kursi (8,18\%), PPP 58 kursi (10,55\%), PKB 52 kursi $(9,45 \%)$, PBB 11 kursi (2\%), dan PKPI 1 (0,12\%). Total kekuatan partai koalisi sebesar 73,33\% (kpu.co.id). Koalisi partai pendukung Presiden SBY tahun 2009 yaitu Partai Demokrat di DPR sebanyak 149 kursi (20,85\%). Presiden SBY kemudian membentuk partai koalisi yaitu Partai Golkar dengan 106 kursi (19,2 \%), PKS 57 kursi (10,54), PPP 37 kursi (6,96\%), dan PKB 28 kursi (5,64 \%), PAN 46 kursi $(7,5 \%)$, Jumlah anggota kekuatan partai koalisi pendukung Presiden di DPR mencapai 75,5\% kursi (kpu.co.id). 
Tabel 1. Peta Kekuatan Partai Koalisi DPR Periode 2004-2009, (KPU)

\begin{tabular}{|l|c|c|r|}
\hline \multicolumn{1}{|c|}{$\begin{array}{c}\text { Partai } \\
\text { Koalisi }\end{array}$} & $\begin{array}{c}\text { Jumlah Kusi } \\
\text { DPR }\end{array}$ & $\begin{array}{c}\text { Partai } \\
\text { Nonkoalisi }\end{array}$ & $\begin{array}{c}\text { Jumlah Kursi } \\
\text { DPR }\end{array}$ \\
\hline Partai Golkar & $128(23,27 \%)$ & PDIP & $109(19,82 \%)$ \\
\hline PPP & $58(10,55 \%)$ & PBR & $14(2,55 \%)$ \\
\hline $\begin{array}{l}\text { Partai } \\
\text { Demokrat }\end{array}$ & $55(7,45 \%)$ & PDS & $13(2,36 \%)$ \\
\hline PAN & $53(9,64 \%)$ & PPDK & $4(0,73 \%)$ \\
\hline PKB & $52(9,45 \%)$ & Partai Pelopor & $3(0,55 \%)$ \\
\hline PKS & $45(8,18 \%)$ & PKPB & $2(0,36 \%)$ \\
\hline PBB & $11(2,00 \%)$ & & \\
\hline PKPI & $1(0,12 \%)$ & & $157(26,7 \%)$ \\
\hline Jumlah & $403(73,3 \%)$ & N=560 & \\
\hline
\end{tabular}

Tabel 2. Peta Kekuatan Partai Koalisi DPR Perode 2009-2014, (KPU)

\begin{tabular}{|l|c|c|c|}
\hline Partai koalisi & Jumlah Kusi DPR & $\begin{array}{c}\text { Partai } \\
\text { Nonkoalisi }\end{array}$ & $\begin{array}{c}\text { Jumlah Kursi } \\
\text { DPR }\end{array}$ \\
\hline Partai Golkar & $106(19,2 \%)$ & PDIP & $95(16,61 \%)$ \\
\hline PPP & $37(6,96 \%)$ & Gerindra & $26(4,36 \%)$ \\
\hline $\begin{array}{l}\text { Partai } \\
\text { Demokrat }\end{array}$ & $149(20,85 \%)$ & Hanura & $16(2,68 \%)$ \\
\hline PAN & $46(7,5 \%)$ & & \\
\hline PKB & $28(5,64 \%)$ & & \\
\hline PKS & $57(10,54)$ & & $137(24,5 \%)$ \\
\hline Jumlah & $423(75,5 \%)$ & $\mathrm{N}=560$ & \\
\hline
\end{tabular}

Tabel: 3. Menteri Kabinet Presiden SBY Berdasarkan Asal Partai Tahun 2004, (Centre for Electoral Reform)

\begin{tabular}{|c|c|}
\hline Partai Politik & Jumlah Menteri \\
\hline Partai Demokrat & 2 \\
\hline Partai Golkar & 2 \\
\hline PPP & 2 \\
\hline PAN & 2 \\
\hline PKB & 2 \\
\hline PKS & 3 \\
\hline PBB & 3 \\
\hline Partai Lain & 2 \\
\hline
\end{tabular}




\section{Kepemimpinan Presiden SBY}

Ciri kepemimpinan Presiden SBY adalah politik akomodatif. Presiden SBY mengakomodasi kepentingan politik elite-elite partai politik terutama yang tergabung dalam partai koalisi pendukung presiden. Ciri kepemimpinan Presiden SBY terlihat dalam membentuk kabinet pada tahun 2004 dan tahun 2009. Presiden SBY setelah dinyatakan sebagai pemenang dalam raihan suara oleh Komisi Pemilihan Umum (KPU) hasil pilpres 2004, membentuk kabinet dengan melibatkan para elite partai koalisi. Komposisi kabinet Presiden SBY berdasarkan asal partai koalisi sebagaimana terdapat pada Tabel 3

Tabel 3 memberikan gambaran bahwa partai politik yang tergabung dalam partai koalisi Presiden SBY melalui partai Demokrat, elite partai memperoleh jatah jabatan duduk di jajaran menteri kabinet. Wakil partai politik yang direkrut Presiden SBY menjadi menteri kabinet hampir merata, termasuk wakil Partai Demokrat yang menjadi partai Presiden SBY. Pertimbangan Presiden SBY merekrut wakil partai duduk dalam kabinet dengan pertimbangan partai yang tergabung dalam koalisi memperoleh kursi yang sama, tanpa memperhatikan jumlah kursi partai di DPR. PBB yang memperoleh kursi paling sedikit sebanyak 11 kursi memperoleh jatah 3 posisi menteri, hal ini diduga faktor hubungan Presiden SBY dengan Yusril Ihza Mahendra selaku Ketua PBB. Menteri yang berasal dari partai sebagaimana Tabel 3 memberikan pemahaman bahwa pertimbangan Presiden SBY membentuk partai koalisi dilandasi pertimbangan kekuasaan yakni 'politik balas jasa' atas kesediaan partai politik untuk berkoalisi dengan Partai Demokrat yang menjadi partai presiden.

Presiden SBY dalam merekrut menteri masih didomisasi oleh perimbangan power sharing dengan partai yang tergabung dengan koalisi yang berjumlah sebanyak 24 menteri, sementara sisanya sebanyak 12 orang berdasarkan legitimasi presiden (hak prerogatif presiden terpilih) yang berasal dari berbagai kelompok profesional. Presiden SBY setahun selama pemerintahannya melakukan dua kali pergantian (reshuffle) menteri yaitu pada tanggal 5 Desember 2005 dan tanggal 7 Mei 2007. Komposisi menteri wakil partai dalam kabinet Presiden SBY dapat dilihat pada Tabel 4.

Tabel: 4. Menteri Kabinet Presiden SBY Hasil Reshuffle Berdasarkan Asal Partai, (Bakir Ihsan, 2011)

\begin{tabular}{|c|c|c|}
\hline Partai Politik & $\begin{array}{c}\text { Jumlah Menteri } \\
\text { Reshuffle 1 }\end{array}$ & $\begin{array}{c}\text { Jumlah Menteri } \\
\text { Reshuffle 2 }\end{array}$ \\
\hline Partai Demokrat & 2 & 4 \\
\hline Partai Golkar & 3 & 2 \\
\hline PPP & 2 & 2 \\
\hline PAN & 2 & 2 \\
\hline PKB & 2 & 2 \\
\hline PKS & 3 & 3 \\
\hline PBB & 3 & 1 \\
\hline Partai lainnya & 2 & 2 \\
\hline
\end{tabular}


Komposisi wakil partai koalisi dalam kabinet Presiden SBY hasil reshuffle 1 dan 2 , terlihat jumlahnya semakin berkurang, dari 24 menteri pada awalnya berkurang menjadi 19 menteri pada hasil reshuffle 1 dan 18 menteri hasil reshuffle 2. Data tersebut memberikan pengetahuan bahwa Presiden SBY semakin mempergunakan legitimasi kekuasaan (hak prerogatif) dalam menyusun kabinet, karena jumlah menteri dari partai koalisi dengan legitimasi kekuasaan terdapat perimbangan yaitu 18 menteri asal partai koalisi dan 8 menteri berasal dari legitimasi kekuasaan Presiden SBY pada reshuffle kabinet 2.

Kompoisisi menteri asal partai koalisi pada tahun 2009, sebanyak 20 menteri berasal dari partai koalisi, 14 orang menteri merupakan pilihan Presiden SBY sendiri. Bakir Ihsan (2011) menyebut bahwa politik Presiden SBY adalah mengakomodir kepentingan elite partai politik yang tergabung dalam partai koalisi pendukung Presiden SBY menjadi menteri kabinet, sebagai imbalan atas dukungan partai kepada Presiden SBY.

Tabel 5. Menteri Kabinet Presiden SBY Berdasarkan Asal Partai Tahun 2009, (Bakir Ihsan, 2011).

\begin{tabular}{|c|c|}
\hline Partai Politik & Jumlah Menteri \\
\hline Partai Demokrat & 6 \\
\hline Partai Golkar & 3 \\
\hline PPP & 2 \\
\hline PAN & 3 \\
\hline PKB & 2 \\
\hline PKS & 4 \\
\hline
\end{tabular}

Ciri kepemimpinan Presiden SBY lainnya adalah menghindari konflik terbuka terutama dengan elite-elite partai koalisi dan DPR. Ciri kepemimpinan ini terlihat dalam kasus Bank Century. Bank Indonesia (BI) pada tanggal 12 November 2008 menyatakan bahwa Bank Century berada dalam pengawasan BI, alasannya karena Bank Century kalah kliring. Faktor ini yang menjadi pemicu BI memberikan Fasilitas Pendanaan Jangka Pendek (FPJP) kepada Bank Century. Pencairan dana bailout ini pada awalnya berjumlah Rp632 miliar, kemudian mencapai angka Rp6,7 triliun (repulika.co.id).

Kasus bailout Bank Century mulai mencuat ke permukaan pascapemilu 2009. Sembilan anggota DPR mengajukan Hak Inisiatif. Anggota dimaksud yaitu Muhammad Misbakhun (F-PKS), Maruarar Sirait (F-PDIP), Bambang Soesatyo (FPG), Andi Rahmat (F-PKS), Chandra Tirta Wijaya (F-PAN), Lili Wahid (PKB), Ahmad kurdi Mukri (PPP), Ahmad Muzani (F-Gerindra), Ahmad Akbar Faizal (Hanura). Alasan anggota DPR adalah kucuran dana bailout sebesar itu tidak rasional dan ada sangkaan bahwa dana tersebut untuk kepentingan Presiden SBY dan Partai Demokrat keperluan pemilu dan pPilpres 2009. Inisistif 9 anggota untuk melaksanakan Hak Angket kasus Bank Century, mendapat dukungan sebanyak 139 anggota DPR, kemudian usulan tersebut diserahkan kepada pimpinan DPR pada 
tanggal 12 November 2009, selanjutnya pimpinan DPR membentuk Pansus Bank Century (beritasatu.com). Pansus Bak Century berjumlah sebanyak 30 orang dengan rincian F-Demokrat sebanak 8 orang, F-Golkar sebanya 6 orang, F-PDIP sebanyak 5 orang, F-PKS sebanyak 3 orang, F-PAN sebanyak 2 orang, F-PKB sebanyak 2 orang, F-PPP sebanyak 2 orang, F-Hanura sebanyak 1 orang, dan FGerindra sebanyak 1 orang.

Rapat Paripurna DPR merumuskan dua opsi menyikapi laporan Pansus Bank Century. Opsi A menyetujui bailout Bank Century untuk mencegah Indonesia dari krisis ekonomi sebagai dampak krisis global. Opsi C menilai kasus Bank Century menunjukkan perbuatan melanggar hukum yang berlanjut penyalahgunaan kekuasaan oleh pejabat otoritas moneter dan fiskal dapat dikualifikasi sebagai tindak pidana korupsi karena diduga merugikan negara. Memeriksa pejabat-pejabat yang bertanggungjawab yang disebutkan namanya oleh Pansus Hak Angket Bank Century melalui aparat penegak hukum, dan DPR membentuk tim pengawas. Pejabat dimaksud adalah Wakil Presiden Budiono dan Menteri Keuangan Sri Mulyani Indrawati.

Sikap faksi-fraksi dalam rapat paripurna DPR telihat pembelahan sikap fraksi-fraksi. F-PG, F-PDIP, F-PKS, F-Hanura, dan F-Gerindra memilih opsi C dengan argumennya masing-masing, F-Demokrat, F-PAN, F-PKB, F-PPP memilih Opsi A. F-PG melalui juru bicaranya Ibnu Munzir menyatakan telah banyak terjadi pelanggaran dan penyimpangan dalam kasus Bank Century. Pejabat-pejabat yang terlibat seperti Budiono, Sri Mulyani Indrawati, Miranda S. Gultom harus diproses melalui jalur hukum. F-PDIP melalui juru bicaranya Puan Maharani menyatakan banyak pelanggaran dan peraturan perbankan dan tindak pidana korupsi dalam kasus Bank Century. Pejabat-pejabat yang bertanggungjawab dibawa ke jalur hukum dan pemerintah harus mengganti uang nasabah. F-Hanura melalui jurubicara Akbar Faizal menyatakan sikapnya memilih opsi C. F-Gerindra juga menyampaikan sikap yang sama dengan F-Hanura memilih opsi C. Sidang Pleno DPR pada tanggal 4 Maret 2010 melakukan voting, untuk menentukan keputusan akhir Bank Century, hasil akhirnya adalah yang memilih Opsi C memperoleh suara sebanyak 315 dan yang memilih Opsi A memperoleh suara sebanyak 212. F-PPP yang semula memilih Opsi A, pada voting memilih Opsi C (hukumonline.com). Sikap pro dan kontra fraksi-fraksi DPR, menunjukkan bahwa koalisi yang dibentuk Presiden SBY bersifat politik pragmatis. Koalisi dibangun untuk mendukung kebijakan presiden meskipun tidak popular, dengan imbalan elite partai memperoleh jatah menteri di kabinet.

Wakil Presiden Budiono melalui rapat Pansus Bank Cenury menyatakan penyelamatan Bank Century sesui dengan koridor hukum. Kejatuhan Bank Century akan memberikan efek domino pada perekonomian nasional. Menteri Keuangan Sri Mulyani menyatakan, pemerintah menyelamatkan Bank Century karena dikhawatirkan berdampak sistemik bagi perbankan nasional. Mantan Wakil Presiden Jusuf Kalla menyatakan bahwa, kegagalan Bank Century bukan karena krisis keuangan, tetapi karena dirampok oleh pemliknya sendiri (bbc.com).

Presiden SBY menyampaikan tanggapannya secara langsung kepada seluruh rakyat Indonesia, begitu selesai Rapat Paripurna Pansus Bank Century. Presiden 
SBY menyatakan kebijakan penyelamatan Bank Century adalah kebijakan yang diambil dalam masa sulit di tengah-tengah puncak krisis ekonomi yang melanda dunia di akhir tahun 2008, keputusan harus diambil agar ekonomi tidak semakin ambruk. Kondisi yang dihadapi ketika itu harga saham anjlok 50\%, rupiah mengalami depresi 30\% lebih menjadi Rp 12.100 untuk satu dolar Amerika Serikat, angka yang terendah semenjak krisis tahun 1997/1998, cadangan devisa turun $12 \%$ menjadi sekitar US\$ 50 miliar (id.wikisource.co).

Presiden SBY membentuk tim khusus Bank Century yang terdiri dari Menteri Hukum dan Hak Asasi Manusia (Menkumham), Jaksa Agung, dan Kepala Kepolisian (Kapolri). Rekomendasi tim khusus Bank Century kepada Presiden SBY adalah tidak perlu menonaktikan Wakil Presiden Budiono dan Menteri Keuangan Sri Mulyani Indrawati. Tim beralasan bahwa penonaktifan harus sesuai prosedur hukum yang berlaku dengan asas praduga tak bersalah. Tim khusus juga beralasan bahwa pejabat negara berhenti sementara setelah memiliki status hukum sebagai terdakwa dan berhenti tetap dari jabatannya setelah mendapat status bersalah berdasarkan hasil putusan pengadilan (antikorupsi.org).

Political deadlock antara Presiden SBY dengan DPR dalam menghadapi kasus Bank Century dapat saja terjadi. Sikap DPR dengan membentuk Pansus Century, dijawab Presiden SBY dengan membentuk Tim Pembelaan yang beranggotakan para menteri kabinet yang membidangi hukum dan keamanan. Dukungan sikap tegas diperlihatkan para elite Partai Demokrat, meminta Presiden SBY mengganti menteri yang berasal dari partai Partai Golkar, PKS, dan PPP, karena ketiga partai tersebut melanggar butir kesepakatan partai koalisi. Presiden SBY untuk menghindari konflik terbuka dengan DPR, memiliki kebijakan lain yakni memperbaharui struktur Setgab Koalisi dengan menunjuk Aburizal Bakrie, Ketua Umum Partai Golkar sebagai Ketua Harian Setgab Koalisi pada tanggal 15 Oktober 2009. Implikasi sikap ini adalah penyelesaian kasus korupsi yang melibatkan pejabat negara seperti kasus Bank Century sebesar Rp6,7 triliun tidak jelas kelanjutannya.

Beberapa kesepakatan Presiden SBY dengan elite-elite partai koalisi berisikan: (1) bersepakat memelihara keutuhan Negara Kesatuan RI; (2) bersepakat melaksanakan sistem presidensial; (3) Presiden akan mengikutsertakan kader parpol sebagai menteri di Kabinet Indonesia Bersatu II; (4) Presiden menetapkan sejumlah nama yang diusulkan menjadi menteri, dan dalam hal lain parpol tidak akan menolak putusan presiden; (5) para menteri wajib melaksanakan tugas sesuai konrak kerja dan berperilaku sesuai dengan integritas yang ditandatangani; (6) Presiden dapat memberhentikan menteri yang tidak memenuhi kontrak kerja dan pakta integritas, Presiden memberitahu pimpinan parpol untuk dicarikan penggantinya; (7) Presiden, baik langsung maupun melalui Wakil Presiden dan para menteri, dapat berkonsultasi ke pimpinan parpol, mengenai kebijakan khusus dan strategis. Parpol anggota koalisi harus mendukung kebijakan yang telah diputuskan Presiden, baik melalui fraksi di DPR maupun saluran lain; (8) dalam menyikapi keputusan dan pelaksanaan tugas di DPR, fraksi partai koalisi selalu berkomunikasi dengan sesama fraksi anggota koalisi; (9) tanpa harus menghilangkan daya kritis dan fungsi pengawasan, fraksi partai koalisi wajib mendukung kebijakan pemerintah 
sebagaimana disebut pada poin 7 dan 8; (10) pimpinan parpol anggota koalisi tidak dapat secara sepihak menarik menterinya yang memiliki masalah internal dengan partainya. Pimpinan parpol harus berkonsultasi dahulu dengan Presiden untuk mencari solusinya; (11) jika pimpinan parpol secara resmi dan terbuka menyatakan menarik dukungan terhadap pemerintahan Presiden Soesilo Bambang Yudhoyono, koalisi atau keberadaan para menteri di kabinet Presiden Soesilo Bambang Yudhoyono-Budiono akan berakhir" (nasional.kompas.com).

Menurut Presiden SBY, Setgab merupakan forum atau fasilitas untuk koordinasi dan konsultasi sesama anggota koalisi, baik eksekutif maupun legislatif, sehingga partai koalisi saling menghormati. Tujuan pembentukan Setgab menurut Presiden SBY agar pemerintahan yang dibangun bisa menjalankan tugasnya secara efektif (tribunnews.com). Kasus Bank Century memperlihatkan ciri kepemimpinan Presiden SBY yang menghindari konflik terbuka dengan elite partai dan DPR.

\section{SIMPULAN}

Sistem presidensial yang dikombinasikan dengan sistem multipartai Indonesia pada masa pemerintahan presiden SBY relatif stabil, selama 10 tahun pemerintahannya, tidak terjadi political deadlock antara presiden dan DPR. Faktor utamanya adalah kepemimpinan Presiden SBY dalam menggunakan kekuasaannya mengedepankan politik akomadasi dan menghindari konflik terbuka dengan DPR dan elite partai politik. Politik akomodasi yang dijalankan Presiden SBY terlihat dalam menyusun kabinet, dengan menyertakan elite partai politik yang tergabung dalam partai koalisi pendukung presiden. Kebijakan Presiden SBY ini sebagai imbalan kepada elite partai yang mendukung pencalonan Presiden SBY dalam Pilpres 2004 dan 2009.

Kepemimpinan Presiden SBY yang bercirikan menghindari konflik terbuka terlihat dalam kasus bailout Bank Century. Elite Partai Demokrat menghendaki menteri yang berasal dari Partai Golkar, PPP dan PKS diganti, karena melanggar kesepakatan partai koalisi pendukung presiden. Ketiga partai tersebut melalui fraksinya di DPR menentang kebijakan Presiden SBY kasus bailout Bank Century sebesar Rp6,7 triliun. Presiden SBY mengambil kebijakan, ketiga elite partai tersebut tetap masuk dalam kabinet dan mengangkat Ketua Umum Partai Golkar Aburizal Bakri sebagai Ketua Harian Setgab. Implikasi model kepemimpinan yang demikian, gagal dalam membokar kasus-kasus korupsi yang berskala besar yang melibatkan pejabat negara.

\section{DAFTAR PUSTAKA}

Assche, Tobias van. (2011). Leadership and and Decision Making, John T. Ishiyama \& Marijke Breuning (Ed), $21^{\text {st }}$ Century Political Sience a Refernce Handbook, Los Angeles-London, New Delhi, Singapore, Wasington DC: Sage Publication Inc. 
Barber, James. D. (1992). The Presidential Character: Predicting performance in the White House, (third edition), Englewood Cliffs, NJ: Prentice Hill.

Cheibub, Jose Antonio. (2007). Presidentialis, Parliamentarism, and Democracy, New.

E. Deen, Rebecca. (2011). "The Presidency,” John T. Ishiyama \& Marijke Breuning (Ed), $21^{\text {st }}$ Century Political Sience a Refernce Handbook, Los AngelesLondon, New Delhi, Singapore, Wasington DC: Sage Publication Inc.

Firman, Noor .(2009). "Menimbang Masa Depan Sistem Presidensial di Indonesia, Problematik Demokrasi dan Kebutuhan Perbaikan Sstem", dalam Moch. Nurhasim \& Ikrar Nusa Bhakti (Penyunting), Sistem Presidensial \& Sosok Presiden Ideal, Yogyakarta: Pustaka Pelajar-Asosiasi Ilmu Politik Indonesia (AIPI).

Harrison, Lisa. (2001). Political Research: An Introdauctin, Routledge: Psychology Press.

Haris, Syamsuddin .(2011). "Koalisi dalam Demokrasi Sistem Presidensial Indonesia: Faktor-Faktor Kerapuhan Koalisi Era Presiden Susilo Bambang Yudhoyono" Jurnal Penelitian Politik, Vol 8, No.1.

Ihsan, A. Bakir. (2011). "Rekonstruksi dan Revitalisasi Koalisi dalam Sistem Quasi Presidensial", Jurnal Penelitian Politik, V18, No.1.

Jensic, Alicia. (2011). Qualitative VS Quantitative Research, John T. Ishiyama \& Marijke Breuning $21^{\text {st }}$ Century Political Sience ARefernce Handbook, Los Angeles-London, New Delhi, Singapore, Wasington DC: Sage Publication Inc.

Kweit, Mary Grisez \& Robert W. Kweit. (1981). Concepts and Methods For Political Analysis, NJ: Prentice-Hall, Inc., Englewood Cliffs.

Kristiadi, J. Sosok Ideal Presiden 2009-2014” dalam Moch. Nurhasim \& Ikrar Nusa Bhakti (Penyunting), Sistem Presidensial \& Sosok Presiden Ideal, Yogyakarta: Pustaka Pelajar-Asosiasi Ilmu Politik Indonesia (AIPI), 2009, Bab. Matthew S. Shugart \&, Carey, J.M (1992). Presidents and Assemblies: Constitutional design and electoral dynamics. Cambridge, UK: Cambridge University Press.

Magenda, Burhan D. (2007).“Dinamika Hubungan Eksekutif Dengan Legislatif Dalam Politik Ketatanegaraan Indonesia”, Jurnal Gloria Juris, Volume 07 No.02. 
Mainwaring, Scott. (1993). "Presidentialisme, Multipartism, and Democracy: The Difficult Combination, dalam Comparative Political Studies, vol.26, No.2, 1993.

Mainwaring, Scott \& Matthew S. Sughart. (1997). Presidensialism and Democracy in Latin America, Cambridge: Cambridge University Press.

Linz, Juan. (1990). "The Perils of Presidensialism, Journal of Democracy 1 (1) 5169. DOI:10.1353/jod.1990.0011.

Lijphart, Arend. (1984). Democracies: Patterns of Majoritarian and Consensus Goverment in Twenty-One Countries, Yale: Yale University.

Lijphart, Arend. (1992).“Introduction", dalam Arend Lijphart (Ed), Parliamentary Versus Government, New York, Oxford University Press.

Lijphart, Arend. (1999). Patterns of Democracy: Government Forms and Performance in

Rauf, Maswadi "Evaluasi Sistem Presidensial "dalam Moch. Nurhasim \& Ikrar Nusa Bhakti (Penyunting), Sistem Presidensial \& Sosok Presiden Ideal, Yogyakarta: Pustaka Pelajar-Asosiasi Ilmu Politik Indonesia (AIPI), 2009, hlm. 33-45.

Romli, Lili. (2019). Sistem Presidensial Indonesia Dinamika, Problematik, dan Penguatan Kelembagaan, Malang: Setara Press.

Robbins, Joseph W .(2011). Presidentialism Versus Parliamentarism, John T. Ishiyama \& Marijke Breuning (Ed), 21st Century Political Sience A Refernce Handbook, Los Angeles-London, New Delhi, Singapore, Wasington DC: Sage Publication Inc.

Smith, M. Brewster. (2009). A Map for Analisys Personality and Politics, Journal of Social Issues, Vol. 24, No. 23.

Subekti, Valina Singka. (2008). Menyusun Konstitusi Transisi Pergulatan Kepentingan dan Pemikiran dalam Proses Perubahan UUD 1945, Jakarta: Rajawali Pers.

Shugart, Matthew S. \&, Carey, J.M. (1992). Presidents and Assemblies: Constitutional design and electoral dynamics. Cambridge, UK: Cambridge University Press. 
Suryadinata, Leo. (1982). Election and Politics in Indonesia, Singapore, ISEAS, 2002.

Widjaja, Albert, Budaya Politik dan Pembangunan Ekonomi, Jakarta: LP3ES.

\section{Internet:}

dpr.go.id, diunduh tanggal 10 Februari 2021.

https://nasional.kompas.com/read/2012/04/05/14560291/Ini.Isi.Perjanjian.SBYParp ol.Koalisi, diunduh tanggal 26 Februari 2021.

https://antikorupsi.org/index.php/id/article/century-dan-sikap-politik-sby, diunduh tanggal 20 Mei 2021.

https://id.wikisource.org/wiki/Pidato_Susilo_Bambang_Yudhoyono_tentang_Hasil_ Akhir_Pansus_Hak_Angket_Bank_Century_DPR-RI, diunduh tanggal 21 Mei 2021.

https://www.bbc.com/indonesia/laporan_khusus/2010/02/100213_bankcenturyplaye rs, diunduh tanggal 18 Mei 2021.

https://www.hukumonline.com/berita/baca/lt4b8ef9a9e72e7/akhir-drama-pansuscentury, dunduh taggal 14 April 2021.

https://www.beritasatu.com/nasional/224300/tim-9-inisiator-pansus-century-yangawalnya-diragukan-jk, diunduh 15 Mei 2021.

https://nasional.kompas.com/read/2012/04/05/14560291/Ini.Isi.Perjanjian.SBYParp ol.Koalisi, diunduh tanggal 26 Februari 2021.

https://www.tribunnews.com/nasional/2010/05/17/sby-setgab-dibetuk-untuk memudahkan koordinasi, dunduh tanggal 27 Februari 2021.

https://www.republika.co.id/berita/n20q0m/ini-kronologis-kasus-bank-century, duunduh 14 Mei 2021. 